\title{
THE NEOTROPICAL ORB-WEAVER GENERA EPEIROIDES, BERTRANA AND AMAZONEPEIRA
} (ARANEAE: ARANEIDAE).*

\author{
By Herbert W. LeVI \\ Museum of Comparative Zoology, Harvard University, \\ Cambridge, Mass. 02138
}

Most Neotropical spider specimens preserved in museums were collected by ornithologists, entomologists or amateur naturalists, who picked up spiders when their preferred organisms could not be found. Invariably such collectors bring back the biggest, showiest spiders. Only in recent years have arachnologists themselves collected, concentrating on the less conspicuous but often more interesting spiders that previously were overlooked. Tiny spiders frequently show greater diversity in structure than larger ones, and have more species in the Holarctic region. At present we know much less about the minute Neotropical Araneidae than about the larger species.

For most of these spiders there is no literature other than catalog citations. Often the second citation is a misidentification, and many species, when found again, were given new names (e.g. Bertrana striolata), because making a new species is much easier than checking previous descriptions and examining their types.

\section{Materials AND MethodS}

Specimens from the following collections were used. I want to thank their curators for their help.

AMNH American Museum of Natural History, New York, N. Platnick, L. Sorkin;

BMNH British Museum (Natural History), London, P. Hillyard, F. Wanless;

CAS California Academy of Sciences, San Francisco, W. J. Pulawski, D. Ubick;

FSCA Florida State Collection of Arthropods, G. B. Edwards; HEC Hope Entomology Collections, Oxford University, D. Spencer-Smith, J. Lansbury;

*Manuscript received by the editor May 8, 1989. 
IRSNB Institut Royal des Sciences Naturelles de Belgique, Brussels, L. Baert;

MCN Museu de Ciências Naturais, Porto Alegre, A. Lise, E. Buckup;

MCZ Museum of Comparative Zoology;

MECN Museo Ecuatoriano de Ciencias Naturales, Quito, L. Avilés;

MEG M. E. Galiano;

MHNSM Museo de Historia Natural, Universidad Nacional Mayor de San Marco's, Lima, D. Silva D.;

MNHN Muséum National d'Histoire Naturelle, Paris, J. Heurtault, J. Kovoor;

MZSP Museu de Zoologia da Universidade de São Paulo, P. Vanzolini, L. Neme, J. L. M. Leme;

MZUF Museo Zoologico de "La Specola," Università, Florence, S. Mascherini;

NHRM Naturhistoriska Riksmuseet, Stockholm, T. Kronestedt;

PAN Polska Akademia Nauk, Warszawa, A. Riedel, W. Starega, J. Proczynski, A. Slojewska;

PMY Peabody Museum, Yale University, C. Remington, D. G. Furth;

USNM National Museum of Natural History, Smithsonian Institution, Washington, D. C., J. Coddington.

The research until recently was supported by National Science Foundation grants: B-5133, GB-36161, BMS 75-05719, DEB 7615568, DEB 79-23004, DEB 80-19732 and BSR 83-12771.

This paper has been made possible by the excellent tiny spider collecting of W. Eberhard, Diana Silva D. and J. Coddington. W. Eberhard, R. E. Coville and C. Griswold provided natural history information. Arno A. Lise made distribution data available. J. Coddington and W. Eberhard read the paper and made useful comments. Dee Woessner helped with the word processing and $\mathrm{L}$. Leibensperger with all aspects of the research. I am grateful to all.

The methods used have been the same as in previous papers (Levi, $1986,1987,1988$ and in press).

\section{Epeiroides Keyserling}

Epeiroides Keyserling, 1884: 523. Type species by monotypy E. bahiensis Keyserling 1884. The gender of the name is feminine (Bonnet, 1956: 1706). 


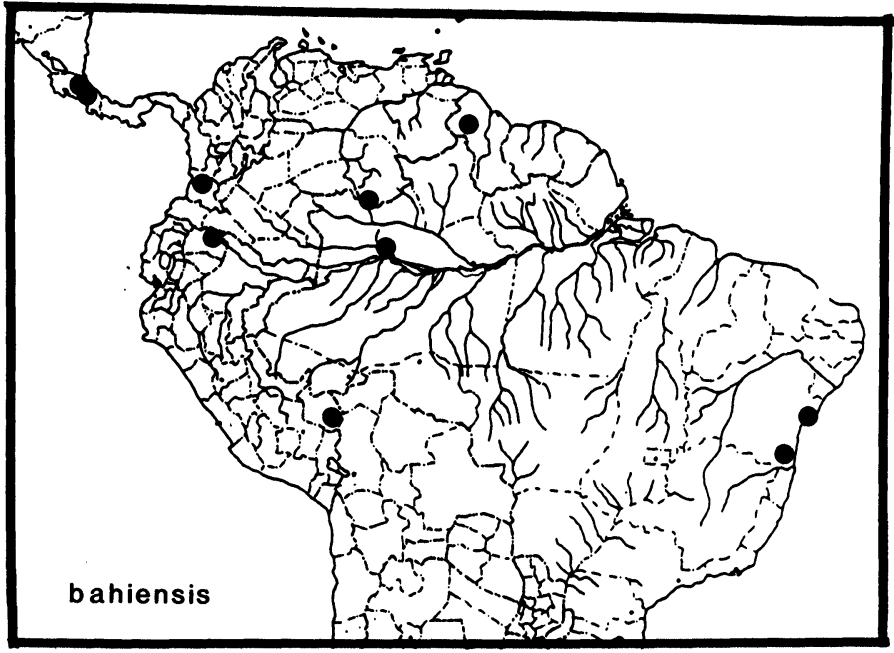

Map 1. Distribution of Epeiroides bahiensis.

Diagnosis. Epeiroides has genitalia resembling those of Alpaida, Wagneriana, Cyclosa and Eriophora. The epigynum of Epeiroides females differs from that of Araneus by lacking an annulate scape with a pocket at its tip. The palpus of male Epeiroides differs from that of Araneus in having the conductor inside the cup formed by the tegulum (not on the rim), and extended basally into a paramedium apophysis. The embolus is similar to that of Alpaida in being fused to the terminal apophysis. (Or is it the embolus lamella?).

Females of Epeiroides bahiensis differ from those of the related Alpaida species and from species of other genera by the unusual apomorph spindle-shaped abdomen and the low, soft carapace. Males differ by having apomorph soft tubercles on the third coxa. The females have hardly any macrosetae on the legs.

Only one species is widespread in the Neotropics (Map 1). The male was heretofore not known.

Misplaced species.

Epeiroides albonotatus Mello Leitão, 1945, is Alpaida truncata (Keyserling).

Epeiroides lamprus Soares and Camargo, 1948, is a Verrucosa. 


\section{Epeiroides bahiensis (Keyserling) \\ Figures 1-10; Map 1}

Epeiroides bahiensis Keyserling, 1885; 524, pl. 13, fig. 23, ᄋ. Female holotype from Bahia, Brazil in MCZ, examined. Keyserling, 1893: 307, pl. 15, fig. 227, ㅇ. Bonnet, 1956: 1706.

Aranea bahiensis:-Roewer, 1942: 837.

Note. The holotype has the tip of the epigynum torn off.

Description. Female from Bahia, Brazil: Carapace yellowish with a pair of minute black spots. Chelicerae, labium, endites yellowish. Sternum yellowish, dusky in center. Coxae yellowish. Legs yellowish; undersides of first and second femora with two black lines, and a dorsal black line from tibiae to tarsi. Dorsum of abdomen yellowish white (Fig. 4); venter dusky with a pair of white spots side by side, spinnerets black (Fig. 5). Eyes subequal. Anterior median eyes two diameters apart, posterior medians one. Legs without macrosetae. Abdomen oval, wider than long (Fig. 4). Total length $6.8 \mathrm{~mm}$. Carapace $3.0 \mathrm{~mm}$ long, 2.7 wide. First femur 4.7 $\mathrm{mm}$, patella and tibia 5.3, metatarsus 4.2 , tarsus 1.1. Second patella and tibia $3.7 \mathrm{~mm}$, third 1.9 , fourth 2.8 .

Male from Colombia: Color as in female. Eyes as in female. Endite with tooth; palpal femur with tooth. Palpal patella with one macroseta. First coxa with hook. Third coxa with tubercles (Fig. 10). Second tibia thicker than first with distal macrosetae (Fig. 9). Legs with macrosetae, second femur with ventral row of macrosetae. Abdomen as wide as long. Total length $4.4 \mathrm{~mm}$. Carapace 2.7 $\mathrm{mm}$ long, 2.3 wide. First femur $4.5 \mathrm{~mm}$, patella and tibia 4.5 , metatarsus 4.0, tarsus 1.2. Second patella and tibia $3.8 \mathrm{~mm}$, third 1.5 , fourth 2.2 .

Variation. The tip of the epigynum is torn off in some specimens (Fig. 2, from Bahia, Brazil); in others it is present (Fig. 1, from Colombia). Total length of females 5.2 to $8.7 \mathrm{~mm}$.

Diagnosis. The epigynum appears quite variable, often with the center torn out (Figs. 1, 2). The palpus has a large conductor (C in Figs. 6-8) and large median apophysis (M). The species appears superficially similar to Araneus sextus (Chamberlin) but differs by the structure of the genitalia (Levi, in press).

Natural History. The web of the female from Costa Rica, a small, vertical orb-web with long foundation lines, was located at the top of stairs leading from the river to the biological station. The 

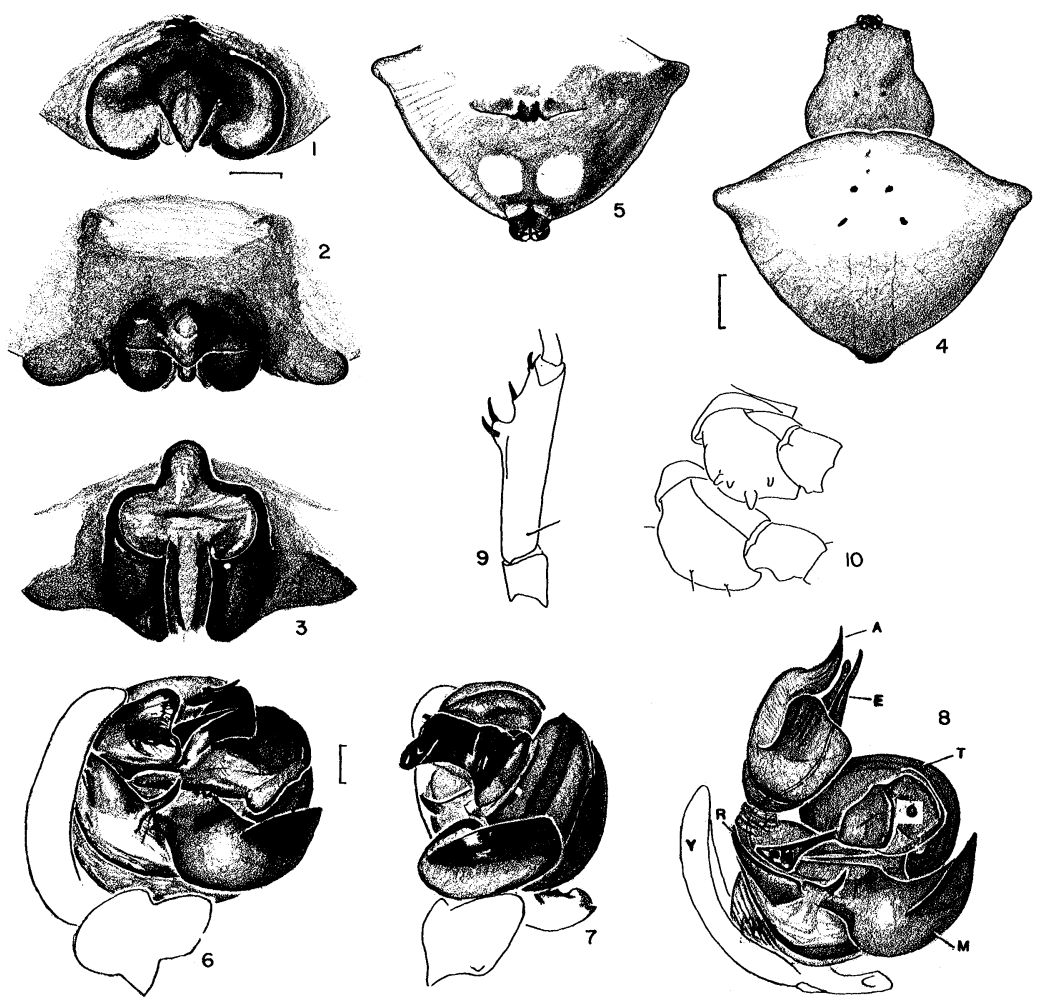

Figures 1-10. Epeiroides bahiensis Keyserling. 1-5, female. 1, 2, epigynum, ventral. 3, epigynum, posterior. 4, dorsal. 5, abdomen, ventral. 6-10, male. 6, left palpus, mesal. 7, palpus, ventral. 8, palpus, pulled apart. 9, left second tibia, ventral. 10, left third and fourth coxae. Abbreviations. A, terminal apophysis; C, conductor; E, embolus; H, hematodocha; M, median apophysis; PM, paramedian apophysis; R, radix; T, tegulum; Y, cymbium. Scale lines. $1.0 \mathrm{~mm}$; genitalia $0.1 \mathrm{~mm}$.

spider was in the hub at first but when disturbed moved to a loosly constructed retreat below the tip of a branch, at the base of three leaves. The spider was clearly visible in the slightly cup-shaped retreat. The orb of the web measured 25 by $25 \mathrm{~cm}$, with a large notched zone but no well-defined hub or free zone. The web was suspended from a bridge measuring $90 \mathrm{~cm}$ on each side of the orb, for a total of $205 \mathrm{~cm}$; a line from the bottom to the substrate measured $45 \mathrm{~cm}$. The species is preyed on by the wasp Trypoxylon 
(Trypargilum) vagulum Richards (Hymenoptera, Sphecidae). (From field notes of C. Griswold, courtesy R. E. Coville, 1986). Other notes are: fell into canoe from overhead vegetation in Venezuela; immature female collected with adult male from under leaf in Colombia.

Records. COSTA RICA Heredia: La Selva nr. Puerto Viejo, Oct. 1981, ㅇ (C. E. Griswold, MCZ). Cartago: Turrialba, $\$$ (Burgdorf-Schild, USNM).

VENEZUELA Amazonas: middle Río Baria, $100 \mathrm{~m}$ el., 21 July 1984, ? (L. S. Ford, C. W. Myers, AMNH). GUYANA Bartica Distr.: Kartabo, 1924, imm (AMNH), COLOMBIA Cauca: ca. 90 km S of Cali, 5 March 1977,, , ô (W. Eberhard, MCZ). ECUADOR Napo: Río Tarapuy, 18 Nov. 1982, + (L. Avilés, MECN). PERU Madre de Dios: Río Tambopata Reserve, $30 \mathrm{~km}$ SW Puerto Maldonado, Nov. 1982, o (E. S. Ross, CAS). BRAZIL Amazonas: Río Japurá, Chicago, 13 Apr. 1915, q (A. Ramon, NHRM). Bahia: Salvador, Oct. 1961, $q$ (N. L. H. Krauss, AMNH); Camacan, $\widehat{o}$ (MCN, 16963).

\section{Bertrana Keyserling}

Bertrana Keyserling, 1884: 654. Type species by monotypy, B. striolata Keyserling 1884. The gender of the name is feminine (Bonnet, 1955: 881).

Diotherisoma di Caporiacco, 1947: 25. Type species by original designation and monotypy, D. strandi di Caporiacco, 1947 (=B. striolata). NEW SYNONYMY.

Diagnosis. Bertrana has genitalia resembling those of Alpaida, Wagneriana, Cyclosa and Eriophora. The epigynum of the female differs from that of Araneus in lacking a long annulate scape on an elaborate base; instead there is a bulge or lobe. The male palpus is distinct from the Araneus palpus by having the conductor inside the cup of the tegulum (not on the rim), and extended basally into a paramedian apophysis. The palpus differs from those of Alpaida, Wagneriana, Cyclosa and Eriophora by a synapomorphy; having the bulb twisted in such a way that the base of the embolus is covered by the cymbium (Figs. 23, 38, 40). The median apophysis is often round and touches the edge of the cymbium (Figs. 17, 30, 50). Unfortunately the small size and the transparency of the sclerites and lack of abundant material makes the study of the palpi difficult.

Bertrana females differ from females of the related Alpaida and other genera by the sparse black pigment in the eye region, the low 
soft carapace, the soft, wider-than-long abdomen, and by their small size, females being less than $5 \mathrm{~mm}$ total length (all presumed synapomorphies). Bertrana includes the smallest known araneid orbweavers.

There are nine species in the Neotropics (Map 2). Only one male, that of B. striolata, was previously known.

All males have 1 palpal patellar seta, all but $B$. vella have a tooth or tubercle on the endite, all but $B$. vella have a coxal hook, and

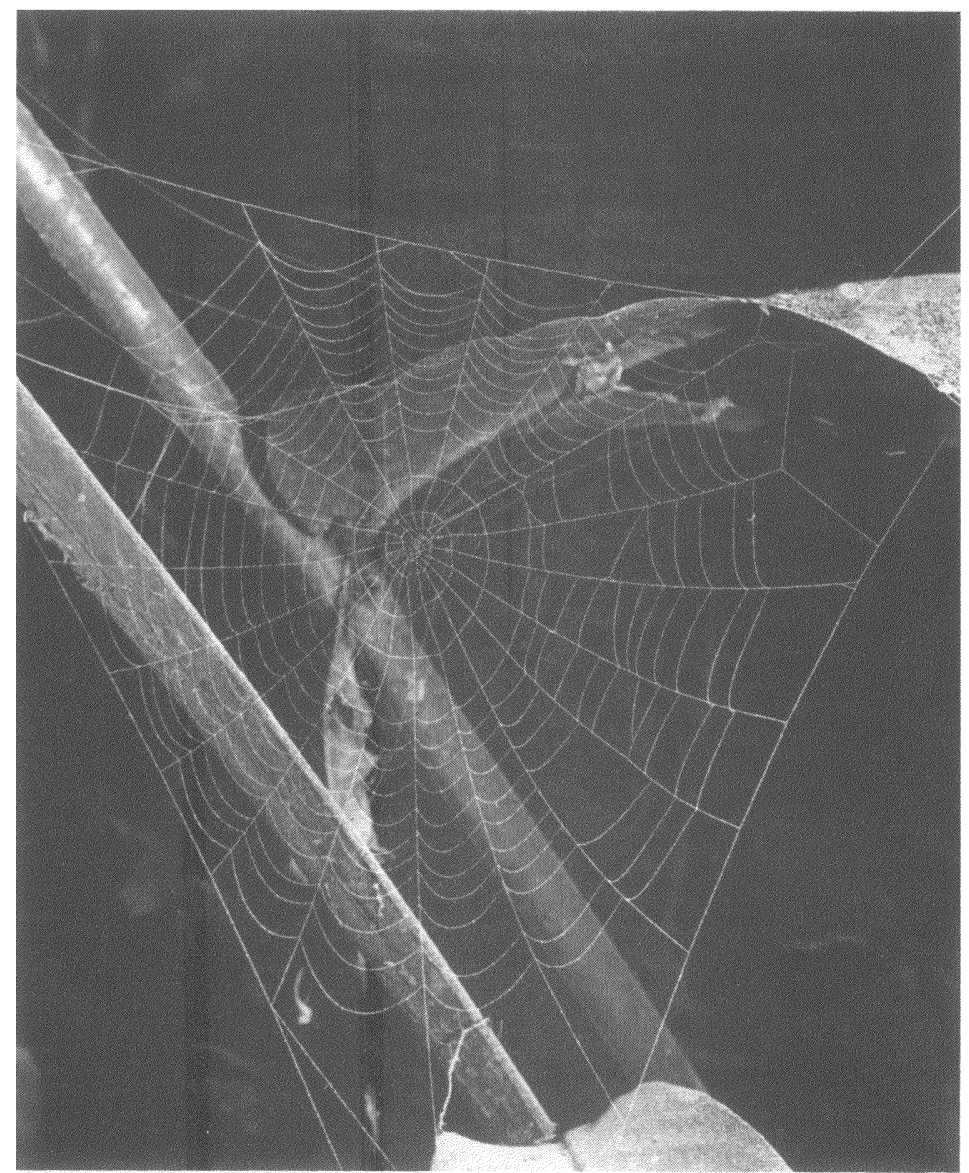

Plate 1. Web of Bertrana laselva, maximum diameter of free zone $4.6 \mathrm{~mm}$; the web was perfectly vertical (photo W. Eberhard). 
only B. elinguis and B. planada have pronounced macrosetae on the second tibia. The second tibia of $B$. laselva is thicker than the first.

Natural History. As far as is known, the species make small, complete, vertical orb-webs (Plate 1) early in the evening, the spiders usually sitting in the hub (B. striolata, B. valle, B. planada, $B$. abbreviata, B. laselva). One individual of $B$. laselva was found near the edge of a web in a retreat, probably a daytime retreat. Several species were collected from early secondary vegetation, $B$. laselva, $B$. planada from streamside, B. valle, B. striolata from roadside (all W. Eberhard, personal communication, 1989).

Misplaced species. Bertrana farri Archer, 1955: 11, figs. 18-21, $24, \widehat{\partial}$, belongs to a new genus to be named.

Key to Bertrana species, females

1. Abdomen marked with numerous lines (Figs. 15, 21) ....2

- Abdomen otherwise .........................

2(1) Epigynum longer than wide (Fig. 19), with an A-shaped posterior depression (Fig. 20); carapace with a pair of dusky marks (Fig. 21) .................... rufostriata

- Epigynum wider than long (Fig. 11), with a wider than long median plate in posterior view (Fig. 12); carapace without dusky marks (Fig. 15) .................. striolata

3(1) Epigynum longer than wide (Fig. 52) .............vella Epigynum as long as wide, or wider than long.........4

4(3) Epigynum constricted at base with a lobe on each side (Figs. $25,26) \ldots \ldots \ldots \ldots \ldots \ldots \ldots \ldots \ldots \ldots$. elinguis

- Epigynum not constricted at base ................

5(4) Carapace and abdomen orange (Fig. 37); epigynum with two dark circles in ventral view, their diameter from posterior margin and touching each other (Fig. 35) .......... laselva

- Coloration and epigynum otherwise ..............6

6(5) A dark mark on each side between head and carapace (Fig. 46); epigynum in posterior view with a pair of sclerites (Fig. 45) $\ldots \ldots \ldots \ldots \ldots \ldots \ldots \ldots \ldots \ldots \ldots \ldots$ arena

- Markings and epigynum otherwise ..............

7(6) Posterior view of epigynum with two dark circles (Fig. 48) planada Posterior view of epigynum otherwise .............. 


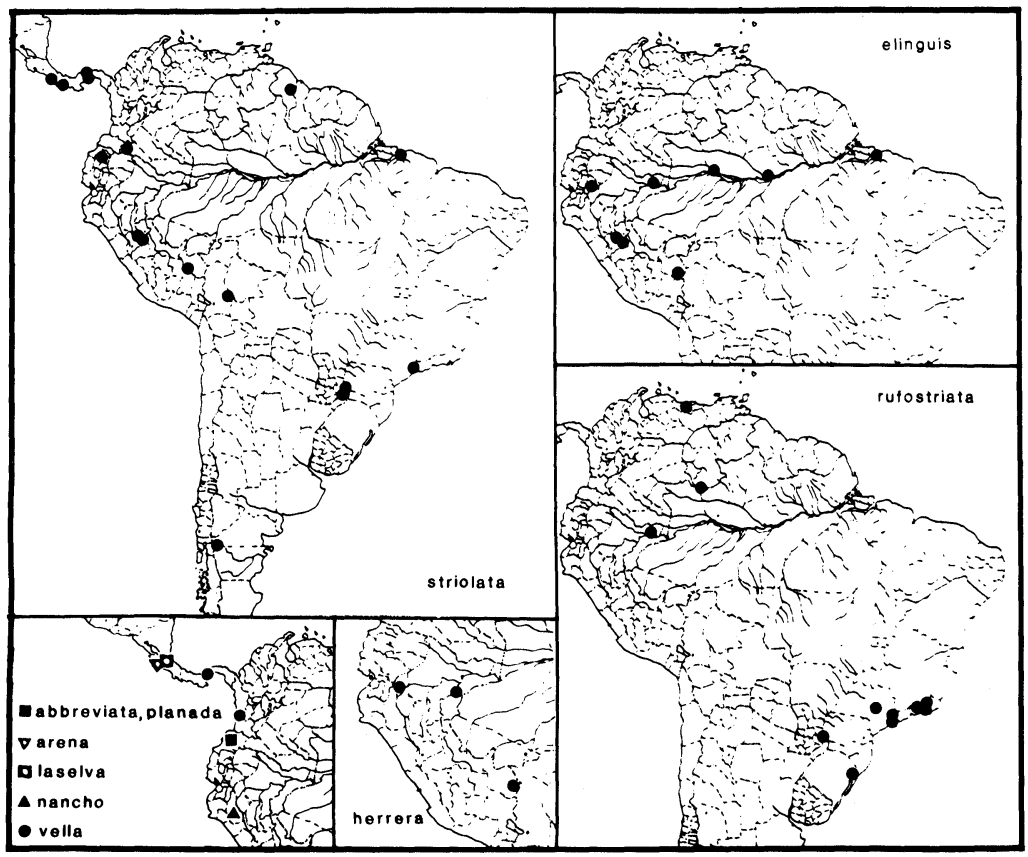

Map 2. Distribution of Bertrana species and Amazonepeira herrera.

8(7) Epigynum in ventral view with sides of median lobe concave (Fig. 41); in posterior view with two parallel lines (Fig. 42)

- Epigynum rounded in ventral view (Fig. 31) and with a Pshaped mark and its mirror image in posterior view (Fig. 32)

Key to Bertrana species, males

1 Abdomen marked with lines (Figs. 18, 24) ...........

- Abdomen otherwise ..........................

2(1) Median apophysis as wide as long; end of terminal apophysis expanded into a knob (Fig. 17) ............. striolata

- Median apophysis much longer than wide; end of terminal apophysis pointed (Fig. 23) ............. rufostriata 
3(2) Tegulum drawn out (Figs. 50, 55) $\ldots \ldots \ldots \ldots \ldots \ldots \ldots 4$

- Tegulum not drawn out.......................

4(3) Tegulum with a projecting bar (Fig. 55) ............vella Tegulum drawn out to a point (Fig. 50) .......... planada

5(3) Median apophysis with large tooth pointing distally to cymbium (Fig. 30) ....................... elinguis

- Median apophysis otherwise (Figs. 38, 39), bulb with characteristic duct loops (Fig. 39) .................. laselva

\section{Bertrana striolata Keyserling}

Figures 11-18; Map 2

Bertrana striolata Keyserling, 1884: 654, pl. 21, fig. 6, \$. According to Keyserling (1884) several female syntypes from Pevas, Amazonas, [Pebas, Loreto, Peru] in the collection Simon. A specimen from La Para [Belém] (MNHN) examined and labeled lectotype. Keyserling 1893: 310, pl. 16, fig. 229, ㅇ. Roewer, 1942: 776. Bonnet, 1955: 881.

Bertrana hieroglyphica Petrunkevitch, 1925: 113, figs. 22-28, $\widehat{\jmath}$. Male holotype from San Lorenzo, Panama (PMY), examined. Roewer, 1942: 776. Bonnet, 1955: 881. Chickering, 1963: 129, figs. 1-4, $q$, $\widehat{o}$. NEW SYNONYMY.

Diotherisoma strandi Di Caporiacco, 1947: 25; 1948: 664, fig. 74, 9 . Female holotype from Two Mouths, near Essequibo River, Guyana (Florence Museum), examined. Brignoli, 1983: 239. NEW SYNONYMY.

Note. Keyserling apparently had specimens of two species, striolata and rufostriata, and illustrated the species here called striolata. A specimen in the BMNH labeled as striolata is actually rufostriata. Also, not all of Keyserling's original specimens may have come from Pevas.

Description. Female from Argentina: Carapace orange-yellow with median white pigment patch. Chelicerae, labium, endites yellow. Sternum orange. Coxae and legs orange-yellow; first and second femora with two ventral black lines; all patellae and tibiae have a dorsal black line; distal ends of first and fourth tibiae with black ring; first tarsus black. Dorsum of abdomen white with black lines bordered by white (Fig. 15); venter dusky. Posterior median eyes 1 diameter of anterior medians, anterior laterals 0.8 diameter, posterior 0.8. Anterior median eyes 1.5 diameters apart, 1 from laterals. Posterior median eyes 0.6 diameter apart, two from laterals. Abdomen spherical (Fig. 15). Total length $3.2 \mathrm{~mm}$. Carapace $1.3 \mathrm{~mm}$ long, 1.2 wide. First femur $1.6 \mathrm{~mm}$, patella and tibia 1.7, metatarsus 


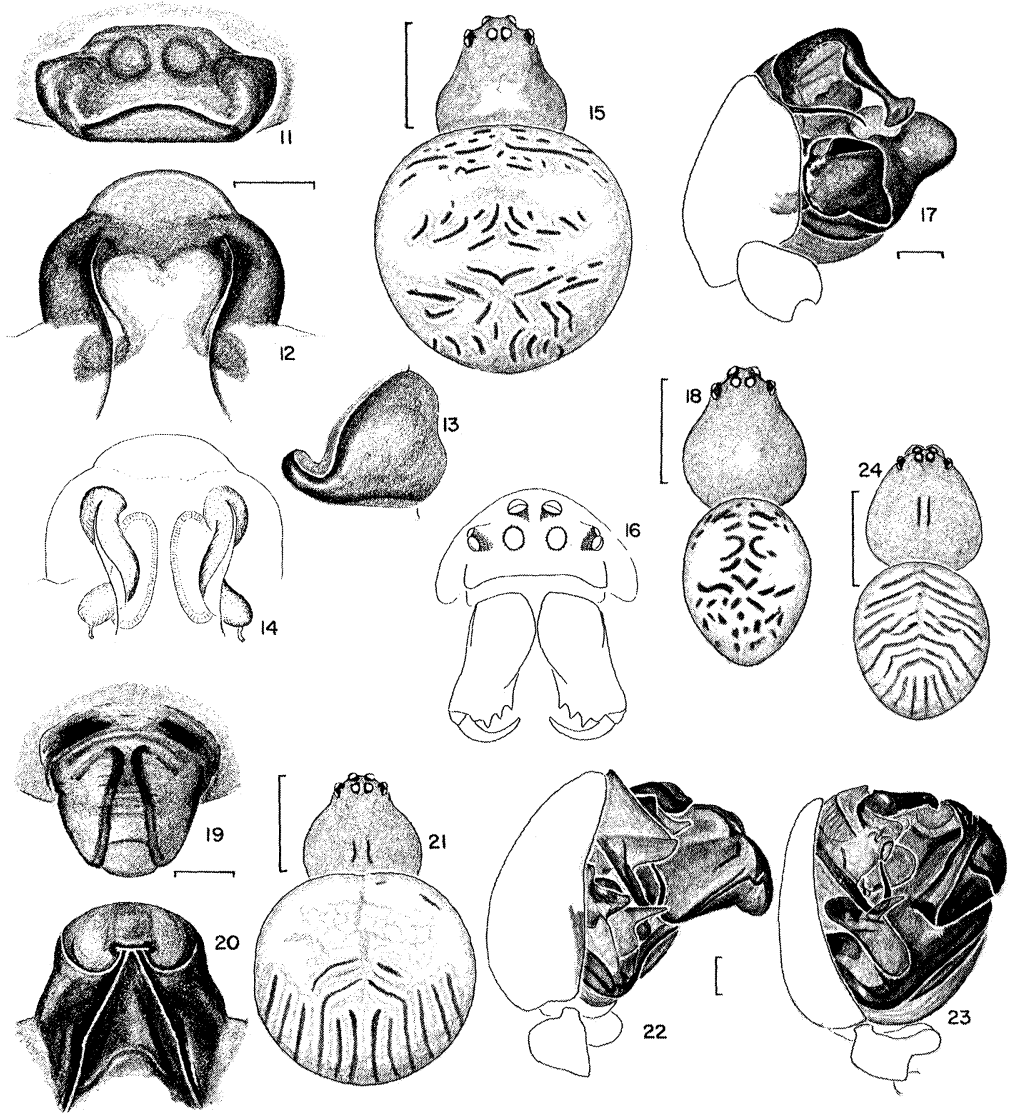

Figures 11-18. Bertrana striolata Keyserling. 11-16, female. 11, epigynum, ventral. 12, epigynum, posterior. 13, epigynum, lateral. 14, epigynum, posterior, cleared. 15 , dorsal. 16, chelicerae and eye region. 17,18 , male. 17, left palpus. 18, dorsal.

Figures 19-24. B. rufostriata Simon. 19-21, female. 19, epigynum, ventral. 20, epigynum, posterior. 21 , dorsal. 22-24, male. 22, 23, palpus. 24, dorsal. Scale lines. $1.0 \mathrm{~mm}$; genitalia $0.1 \mathrm{~mm}$.

1.2 , tarsus 0.4 . Second patella and tibia $1.3 \mathrm{~mm}$, third 0.8 , fourth 1.2 .

Male from Panama: Color as in female (Fig. 18). Posterior median eyes 1 diameter of anterior medians, anterior laterals 0.8 diameter, posterior laterals 0.8 . Anterior median eyes 1.5 diameters 
apart, 1 from laterals. Posterior median eyes 0.6 diameter apart, 2 from laterals. Endite and palpal femur each with a tooth. Palpal patella with one macroseta. First coxa with large projecting hook. Neither first nor second tibia modified. Second femur with short groove. Fourth trochanter with one short macroseta. Abdomen oval. Total length $2.5 \mathrm{~mm}$. Carapace $1.3 \mathrm{~mm}$ long, 1.0 wide. First femur $1.4 \mathrm{~mm}$, patella and tibia 1.7 , metatarsus 1.1 , tarsus 0.4 . Second patella and tibia $1.3 \mathrm{~mm}$, third 0.7 , fourth 1.0 .

Note. Figures 11-13, 16 were made from the lectotype, 15 from an Argentinian specimen, 17, 18 from a Panamanian specimen.

Variation. Total length of females 2.4 to $3.8 \mathrm{~mm}$, males 2.2 to $2.6 \mathrm{~mm}$. One female has the tip of the epigynum torn off.

Diagnosis. Bertrana striolata differs from B. rufostriata by having the epigynum wider than long (Fig. 12), and the male palpus with a median apophysis as wide as long and a knob at the tip of the terminal apophysis (Fig. 17).

Natural History. Found in forest understory (W. Eberhard, personal comm.)

Distribution. From Costa Rica to Argentina (Map 2).

Records. COSTA RICA Puntarenas: vicinity of Piedras Blancas, 23 July 1981, ô (G. B. Edwards, FSCA); Osa Peninsula, $2.5 \mathrm{mi}$. SW Rincon, March 1967, \& (Organ. Trop. Studies, MCZ). PANAMA Panamá: Pedro Miguel; Forest Reserve; Experimental Gardens; Balboa; Madden Dam; Cerro Galero; Summit; Cocoli area; Barro Colorado Island, Gatun Lake (all MCZ). COLOMBIA Putumayo:

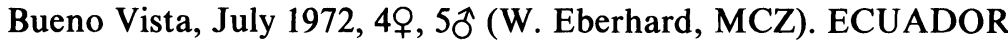
Pichincha: $4 \mathrm{~km}$ NE Pedro Maldonado, km 113 to Puerto Quito, $0^{\circ} 05^{\prime}, 7^{\circ} 07^{\prime}, 9-12$ July 1988, ㅇ, $\hat{o}$ (W. Maddison, MCZ). PERU Huánuco: Tingo María, 10 Oct. 1954, 3 ㅇ (E. I. Schlinger, E. S. Ross, CAS); Dantas La Molina, SW of Puerto Inca, $270 \mathrm{~m}, 09^{\circ} 38^{\prime}$, 7500', 18 May-1 June 1987, o (D. Silva D, MHNSM). Madre de Dios: Atalaya, Río Carbón, 23 Sep. 1987, 29, 10ิ (D. Silva, MHNSM). BRAZIL São Paulo: Baruerí, 6 Dec. 1965, 3o, ồ (K. Henohocol, MZSP 5873), 20 Dec. 1965, o (K. Lenko, MZSP 9576); Jundiaí, Nov. 1976, đ̂ (P. Schneble, MCZ). BOLIVIA La Paz: Chulumani, $1700 \mathrm{~m}$, Yungas, $q$ (L. Peña, IRSN). ARGENTINA Misiones: Eldorado, Nov. 1970, ô (M. E. Galiano, MEG); Sep.-Nov. 1964, \& (A. Kovacs, AMNH); Gral. Manuel Belgrano, Jan. 1966, đ̊ (M. E. Galiano, MEG); Parque Nac. Iguazu, Jan. 
1966, ô, Oct. 1977, ㅇ (M. E. Galiano, MEG); Cataratas de Iguazu, 5 Oct. 1963, $q, 26$ March 1968, \& (M. E. Galiano, MEG). Río Negro: El Bolson, 1965, 1966, ô (A. Kovacs, AMNH).

\section{Bertrana rufostriata Simon}

Figures 19-24; Map 2

Bertrana rufostriata Simon, 1893: 325. Female holotype from Pebas, [Dpto. Loreto], Peru in MNHN, examined. Roewer, 1942: 776. Bonnet, 1955: 881.

Description. Female holotype: Carapace, chelicerae, labium, endites, sternum orange-yellow. Coxae, legs orange-yellow, tarsi dusky. Dorsum of abdomen white with dusky streaks (Fig. 21); sides with small white spots, venter with some dusky pigment. Eyes subequal. Anterior median eyes 1.5 diameters apart, 1.5 from laterals. Posterior median eyes their diameter apart, 2.5 from laterals. Posterior median eyes their diameter apart, 2.5 from laterals. Abdomen spherical (Fig. 21). Total length $3.4 \mathrm{~mm}$. Carapace $1.3 \mathrm{~mm}$ long, 1.2 wide. First femur $1.7 \mathrm{~mm}$, patella and tibia 1.9, metatarsus 1.4 , tarsus 0.4. Second patella and tibia $1.8 \mathrm{~mm}$, third 0.7 , fourth 1.4 .

Male from São Paulo: Color as in female but carapace with two short dusky marks (Fig. 24), legs with black lines under femora and tibiae, and abdomen with a transverse dusky bar in front of spinnerets. Eyes subequal. Anterior median eyes slightly more than a diameter apart, one from laterals. Posterior median eyes slightly less than 1 diameter apart, 2.5 from laterals. Endite with tooth. Palpal patella with one macroseta. First coxa with hook. Abdomen oval, longer than wide. Total length $2.7 \mathrm{~mm}$. Carapace $1.3 \mathrm{~mm}$ long, 1.3 wide. First femur $1.4 \mathrm{~mm}$, patella and tibia 2.2, metatarsus 1.5 , tarsus 0.9. Second patella and tibia $1.4 \mathrm{~mm}$, third 0.7, fourth 1.4.

Note. Figures 19, 20 were made from the holotype, 21-23 from specimens from São Paulo.

Variation. Total length of females 3.2 to $4.3 \mathrm{~mm}$, males 2.7 to $2.8 \mathrm{~mm}$.

Diagnosis. The female differs from that of $B$. striolata by having the epigynum much longer than wide in slightly anterior view, and having a triangular depression in posterior view (Figs. 19-20). The male differs by the structure of the palpus (Figs. 22-23).

Records. VENEZUELA Aragua: Henri Pittier Natl. Park, Rancho Grande, 18 Feb. 1984, o (J. Coddington, USNM). Amazonas: Cerro de la Neblina, camp 12, 1950 m, 26 Feb. 1985 (W. Beck et 
al., USNM). BRAZIL Rio de Janeiro: Teresópolis, 900-1000 m, March 1946, o (H. Sick, AMNH); Nova Iguaçu, Miguel Couto, July 1961, \& (M. Alvarenga, AMNH); Petrópolis, Nov. 1945, ᄋ (H. Sick, AMNH). São Paulo: São Paulo, Feb.-March 1959. 22, ô (F. Lane, AMNH); Bosque da Saúda, capital, Dec. 1940, o (F. Lane, MZSP 9646); São Paulo, botanical garden, forest, 10 Apr. 1965, ㅇ (H. Levi, P. de Biasi, MCZ); camino de mar, 33 km S São Paulo, forest, fields, 11 Apr. 1965, ㅇ (H. Levi, P. de Biasi, MCZ); Agua Funda, Capital, 13 Aug. 1965, \& (K. Lenko, MZSP 4495); Boracéia, 1 Feb. 1961, ô (K. Lenko, MZSP 9586); 28 Feb. 1967, 2 (P. Biasi, MZSP 6143); Engh. Marcilac, 12 March 1967, 3우, ô (P. Biasi, MZSP 6014); Ribeirão Pires, June 1954, ㅇ (N. L. H. Krauss, AMNH); Santos, 24-27 June 1962, \& (A. F. Archer, AMNH); Santo André, 19 Nov. 1941, ㅇ (J. Domigo, MZSP 9642). Paraná: Iguaçu Falls, 4 Oct. 1965, 2 (H. Heatwole, AMNH). Santa Catarina: Est. S. Bento, Corupá, Alto Serra, Rancho Maller, 3 May 1967, o (P. Biasi, MZSP 7005). Rio Grande do Sul: Igrejinha [Taquara], 19 Oct. 1967, o (P. Biasi, MZSP 7162).

\section{Bertrana elinguis (Keyserling) new combination}

Figures 25-30; Map 2

Epeira elinguis Keyserling, 1883: 198, pl. 15, fig. 4, 9. Female holotype from Amazonas, Brazil, in HEC, examined. Keyserling, 1892: 151, pl. 8, fig. 111, $q$.

Bertrana flavosellata Simon, 1893: 326. Female holotype from "Para and Amazonas" in MNHN, examined. NEW SYNONYMY.

Aranea elinguis: - Roewer, 1942: 841.

Araneus elinguis: - Bonnet, 1955: 500.

Description. Female from Madre de Dios, Peru, for coloration; measurements from holotype: Carapace orange. Chelicerae, labium, endites, sternum orange-red. Coxae, legs orange-red. Dorsum of abdomen dull yellowish with four dark red transverse stripes and dark red spots on two yellow patches; sides purplish red (Fig. 29); venter purplish red; epigynum red-brown. Posterior median eyes $\mathbf{0 . 6}$ diameter of anterior medians, laterals 0.6 diameter. Anterior median eyes slightly more than one diameter apart, the same distance from laterals. Posterior median eyes their diameter apart, 2 from laterals. Abdomen subspherical, wider than long (Figs. 28-29). Total length $3.0 \mathrm{~mm}$. Carapace $1.2 \mathrm{~mm}$ long, 1.2 wide. First femur $1.4 \mathrm{~mm}$, patella and tibia 1.7 , metatarsus 1.0 , tarsus 0.4 . Second patella and tibia $1.2 \mathrm{~mm}$, third 0.7 , fourth 1.2 . 

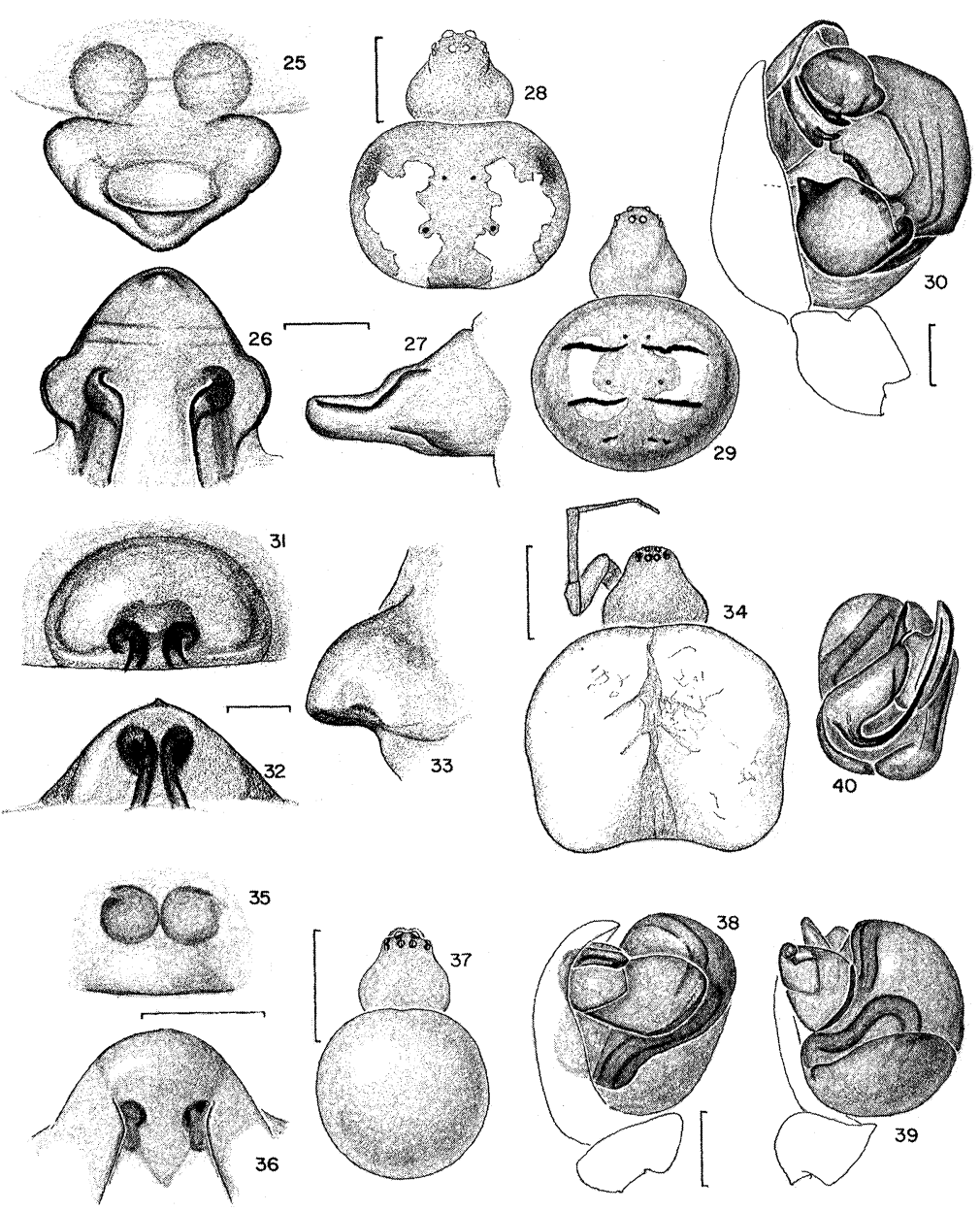

Figures 25-30. Bertrana elinguis (Keyserling). 25-29, female. 25, epigynum, ventral. 26, epigynum, posterior. 27 , epigynum, lateral. 28,29 , dorsal. 30 , male, left palpus.

Figures 31-34. B. abbreviata (Keyserling), female. 31, epigynum, ventral. 32, epigynum, posterior. 33 , epigynum, lateral. 34 , dorsal.

Figures 35-40. B. laselva n. sp. 35-37, female. 35, epigynum, ventral. 36, epigynum, posterior. 37 , dorsal. $38-40$, male palpus. 38 , mesal. 39 , ventral. 40 , dorsal, cymbium removed. Scale lines. $1.0 \mathrm{~mm}$; genitalia $0.1 \mathrm{~mm}$. 
Male from Rio Ampiacu: Color as in female but with two pairs of transverse white marks on the abdomen. Posterior median eyes 0.7 diameter of anterior medians, anterior laterals 0.7 diameter, posterior laterals 0.6. Anterior median eyes 0.9 diameter apart, 0.4 from laterals. Posterior median eyes 0.5 diameter apart, 2.3 from laterals. Endite with large tooth, palpal femur with proximal tubercle. Palpal patella with one macroseta. First coxa with hook. Second tibia thicker than first with several prolateral macrosetae. Abdomen oval, longer than wide. Total length $2.5 \mathrm{~mm}$. Carapace $1.3 \mathrm{~mm}$ long, 1.2 wide. First femur $1.6 \mathrm{~mm}$, patella and tibia 1.8, metatarsus 1.2, tarsus 0.5. Second patella and tibia $1.2 \mathrm{~mm}$, third 0.7, fourth 1.2 .

Note. Males and females have not been collected together. They are matched on the basis of similar orange coloration and lack of black pigment around the eyes. Figures 25-28 were made from the holotype of Epeira elinguis, Figures 29-30 from some recently collected specimens from Peru.

Variation. Specimens that have stayed in alcohol for some time are completely yellowish white with two white abdominal patches; there is no black eye pigment. Total length of females 2.4 to $3.0 \mathrm{~mm}$.

Diagnosis. The coloration also separates the species from other Bertrana. The epigynum has a characteristic lobe on each side, where it is wider than at its attachment to the abdomen (Fig. 25-26). The palpus of the male has a nearly circular median apophysis with a distal sclerotized point (Fig. 30).

Records. ECUADOR Morona-Santiago: Los Tayos, $03^{\circ} 10^{\prime}$, $78^{\circ} 12^{\prime}$, \& (MCZ). PERU Loreto: Estiron, Río Ampiyacu, 13 Nov.9 Dec. 1961, 4ổ (B. Malkin, AMNH). Huánuco: Dantas-La Molina, Quebrada Sapote, SW Puerto Inca, $270 \mathrm{~m}, 09^{\circ} 38^{\prime}, 75^{\circ} 00^{\prime}$, May 1987, 2 (D. Silva D, MNHSM); Monzón Valley, 12, 19 Oct. 1954, 2 (E. Schlinger, E. S. Ross, CAS). Madre de Dios: Tambopata Reserve, Río Tambopata, 30, March 1988, o' (J. Palmer, D. Smith, MCZ), 2 July 1987, ( (D. Silva, MHSM). BRAZIL Amazonas: Manaus, Reserva Ducke, Aug. 1971, \& (M. E. Galiano, MEG). Igarape Belém, nr. confluence with Rio Solimões, 5-30 April 1966, $\hat{o}$ (B. Malkin, AMNH). 
Bertrana abbreviata (Keyserling), new combination

Figures 31-34; Map 2

Singa abbreviata Keyserling, 1879: 301, pl. 4, fig. 5, ᄋ. Female holotype from Neu

Granada [Spanish colony of Colombia and Panama] in BMNH, examined;

Keyserling, 1893: 287, pl. 15, fig. 212, ㅇ. Roewer, 1942: 876.

Araneus abbreviatus: - Bonnet, 1955: 419.

Description. Female from Nariño, Colombia: Carapace yellow, with large black rings around eyes. Chelicerae, labium, endites yellowish. Sternum black. Coxae, legs yellowish. Dorsum of abdomen with white spots, some gray in midline (Fig. 34); venter with small white spots in the center, large white spots on sides of abdomen (Fig. 34). Posterior median eyes 1.5 diameters of anterior medians, anterior laterals 1.3 diameters, posterior 1.3. Anterior median eyes 1.3 diameters apart, 1 from laterals. Posterior median eyes their diameter apart, 1.8 from laterals. Abdomen wider than long, bulging on each side (Fig. 34). Total length $1.6 \mathrm{~mm}$. Carapace $0.7 \mathrm{~mm}$ long, 0.7 wide. First femur $0.85 \mathrm{~mm}$, patella and tibia 0.84 , metatarsus 0.61 , tarsus 0.39 . Second patella and tibia $0.74 \mathrm{~mm}$, third 0.53 , fourth 0.33 .

Note. The illustrations were made from the holotype.

Variation. According to Keyserling $(1879,1893)$ the total length of the holotype is $3.5 \mathrm{~mm}$.

Diagnosis. The protruding shape of the epigynum and its posterior marks (Figs. 31-33) separate B. abbreviata from other Bertrana species.

Records. COLOMBIA Nariño: La Planada, 1800 m, 7 km S. Choconés, July 1986, 우 (W. Eberhard 3348, MCZ).

Bertrana laselva new species

Plate 1; Figures 35-40; Map 2

Holotype. Female holotype and male paratype from La Selva near Puerto Viejo, Heredia Prov., Costa Rica, 26 March 1979 (J. Coddington) in MCZ. The specific name is a noun in apposition after the type locality.

Description. Female holotype: Carapace orange, with black pigment behind eyes only. Chelicerae, labium, endites orange, sternum orange. Coxae, legs orange. Dorsum of abdomen light orange 
(Fig. 37). Posterior median eyes 0.9 diameter of anterior medians, laterals 0.8 diameter. Anterior median eyes 1 diameter apart, 0.5 from laterals. Posterior median eyes their diameter apart, 1.2 from laterals. Abdomen spherical (Fig. 37). Total length $2.3 \mathrm{~mm}$. Carapace $0.87 \mathrm{~mm}$ long, 0.84 wide. First femur $1.27 \mathrm{~mm}$, patella and tibia 1.32 , metatarsus 0.97 , tarsus 0.48 . Second patella and tibia 1.05 $\mathrm{mm}$, third 0.84 , fourth 1.06 .

Male paratype: Color as in female. Eyes subequal. Anterior median eyes slightly more than 1 diameter apart, 0.4 from laterals. Posterior median eyes 1 diameter apart, 0.5 from laterals. Endite with tubercles, palpal femur with tubercle near proximal end. Palpal patella with one macroseta. First coxa with hook. Second tibia thicker than first, without macrosetae. Abdomen subspherical, narrower than that of female. Total length $1.7 \mathrm{~mm}$. Carapace $0.87 \mathrm{~mm}$ long, 0.65 wide. First femur $1.30 \mathrm{~mm}$, patella and tibia 1.39, metatarsus 1.04 , tarsus 0.49 . Second patella and tibia $0.91 \mathrm{~mm}$, third 0.65 , fourth 1.00 .

Variation. Living specimens are bright orange with carapace and sternum red. Some females have the abdomen covered by tiny white pigment spots. Total length of females 1.7 to $2.2 \mathrm{~mm}$.

Diagnosis. The bright orange coloration separates this from other species. The weakly sclerotized epigynum shows a pair of seminal receptacles less than their diameter from the margin (Fig. 35 ), with a transverse swelling behind. The lightly sclerotized male palpus shows a diagnostic loop of the duct (Figs. 38, 39).

Paratypes. COSTA RICA Heredia: La Selva nr. Puerta Viejo, Jan. 1978, ô (W. Eberhard, MCZ); 20 March 1979, ㅇ, 26 March 1979, \& (J. Coddington, MCZ, USNM); Dec. 1980, 3ㅇ, June 1982,

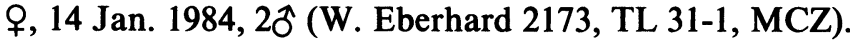

\section{Bertrana nancho new species}

Figures 41-43; Map 2

Holotype. Female holotype from Montaña di Nancho [Nanchoc], $7700 \mathrm{ft}$. [2350 m], Cajamarca, Peru, [06 ${ }^{\circ} 58^{\prime}, 79^{\circ} 15^{\prime}, 70 \mathrm{~km}$ from Chaclayo] (K. Jelski, J. Sztolcman) in PAN. The specific name is a noun in apposition after the original spelling of the type locality. 
Description. Female holotype: Carapace yellowish, sides of carapace dusky, some red around eyes. Chelicerae dusky yellowish. Labium, endites brown-black. Sternum black. Coxae yellowish. Legs yellowish, first and second with dusky longitudinal patches, third and fourth with dusky rings. Dorsum of abdomen speckled (Fig. 43); venter with a pair of large, round, white spots their diameter apart. Eyes subequal. Anterior median eyes slightly more than 1 diameter apart, 1 from laterals. Posterior median eyes slightly less than their diameter apart, 2 from laterals. Abdomen transverserectangular with paired posterior humps, and paired indistinct anterior humps (Fig. 43). Total length $2.3 \mathrm{~mm}$. Carapace $1.07 \mathrm{~mm}$ long, 1.03 wide. First femur $1.14 \mathrm{~mm}$, patella and tibia 1.21 , metatarsus 0.68 , tarsus 0.44 . Second patella and tibia $1.07 \mathrm{~mm}$, third 0.72 , fourth 1.12 .

Diagnosis. In the epigynum of B. nancho, unlike other Bertrana species, the median lobe has concave sides (Fig. 41) and two parallel lines in posterior view (Fig. 42).

\section{Bertrana arena new species}

Figures 44-46; Map 2

Holotype. Female holotype from Monteverde Biological Reserve, Puntarenas Province, Costa Rica, 3 April, 1979 (J. Coddington) in MCZ. The specific name is an arbitrary combination of letters.

Description. Female holotype: Carapace yellowish white with a discrete, gray oval on each side of head. Chelicerae, labium, endites, sternum, coxae, legs yellowish white. Dorsum of abdomen with two white patches of irregular outline on yellowish white (Fig. 46); venter yellowish white. Eyes subequal. Anterior median eyes slightly more than their diameter apart, 1.3 from laterals. Posterior median eyes slightly more than their diameter apart, 2.2 from laterals. Abdomen wider than long (Fig. 46). Total length $2.7 \mathrm{~mm}$. Carapace $1.17 \mathrm{~mm}$ long, 1.17 wide. First femur $1.14 \mathrm{~mm}$, patella and tibia 1.22 , metatarsus 0.81 , tarsus 0.46 . Second patella and tibia $1.04 \mathrm{~mm}$, third 0.78 , fourth 1.13 .

Diagnosis. Bertrana arena differs from other species by the epigynum, which has separate lateral sclerites in posterior view (Fig. 45). 


\section{Bertrana planada new species}

Figures 47-50; Map 2

Holotype. Female holotype and female paratype from La Planada, $1800 \mathrm{~m}, 7 \mathrm{~km}$ south of Chocones, Nariño, Colombia, July 1986 (W. Eberhard 3349) in MCZ. The specific name is a noun in apposition after the type locality.

Description. Female holotype: Carapace yellowish, sides of thorax dusky. Chelicerae, labium, endites yellowish. Sternum black. Coxae, legs yellowish. Dorsum of abdomen with black and white pattern (Fig. 49); venter dusky with a wide, white, longitudinal band on each side. Posterior median eyes 1.1 diameters of anterior medians, anterior lateral eyes 1.1 diameters, posterior eyes 1 diameter. Anterior median eyes 1.2 diameters apart, 1.2 from laterals. Posterior median eyes their diameter apart, two from laterals. Abdomen wider than long, bulging posteriorly on each side (Fig. 49). Total length $1.7 \mathrm{~mm}$. Carapace $0.85 \mathrm{~mm}$ long, 0.80 wide. First femur 0.84 $\mathrm{mm}$, patella and tibia 0.91 , metatarsus 0.59 , tarsus 0.33 . Second patella and tibia $0.71 \mathrm{~mm}$, third 0.52 , fourth 0.83 .

Male from Tungurahua, Ecuador: Color as in female. Eyes subequal. Anterior median eyes 1.5 diameters apart, 1.5 from laterals. Posterior median eyes 1.5 diameters apart, 3 from laterals. Endite with tooth, palpal femur with tooth. Palpal patella with one macroseta. First coxa with hook. Second femur with a ventral row of macrosetae. Second tibia slightly thicker than first. Abdomen wider than long. Total length $2.2 \mathrm{~mm}$. Carapace $1.31 \mathrm{~mm}$ long, 1.20 wide. First femur $1.34 \mathrm{~mm}$, patella and tibia 1.46. Second patella and tibia $1.04 \mathrm{~mm}$, third 0.82 , fourth 1.07 .

Note. It is not certain that the male and females are correctly matched. The male is larger than the holotype specimen, but shrivelled.

Variation. The abdomen of different females varies from subspherical to wider than long; apparently it is soft and easily damaged. Total length of females 1.7 to $2.9 \mathrm{~mm}$.

Diagnosis. The female differs from other species by having two round, dark depressions on the posterior face of the epigynum (Fig. 48); the male differs by having the tegulum of the palpus drawn out to a point (Fig. 50). 

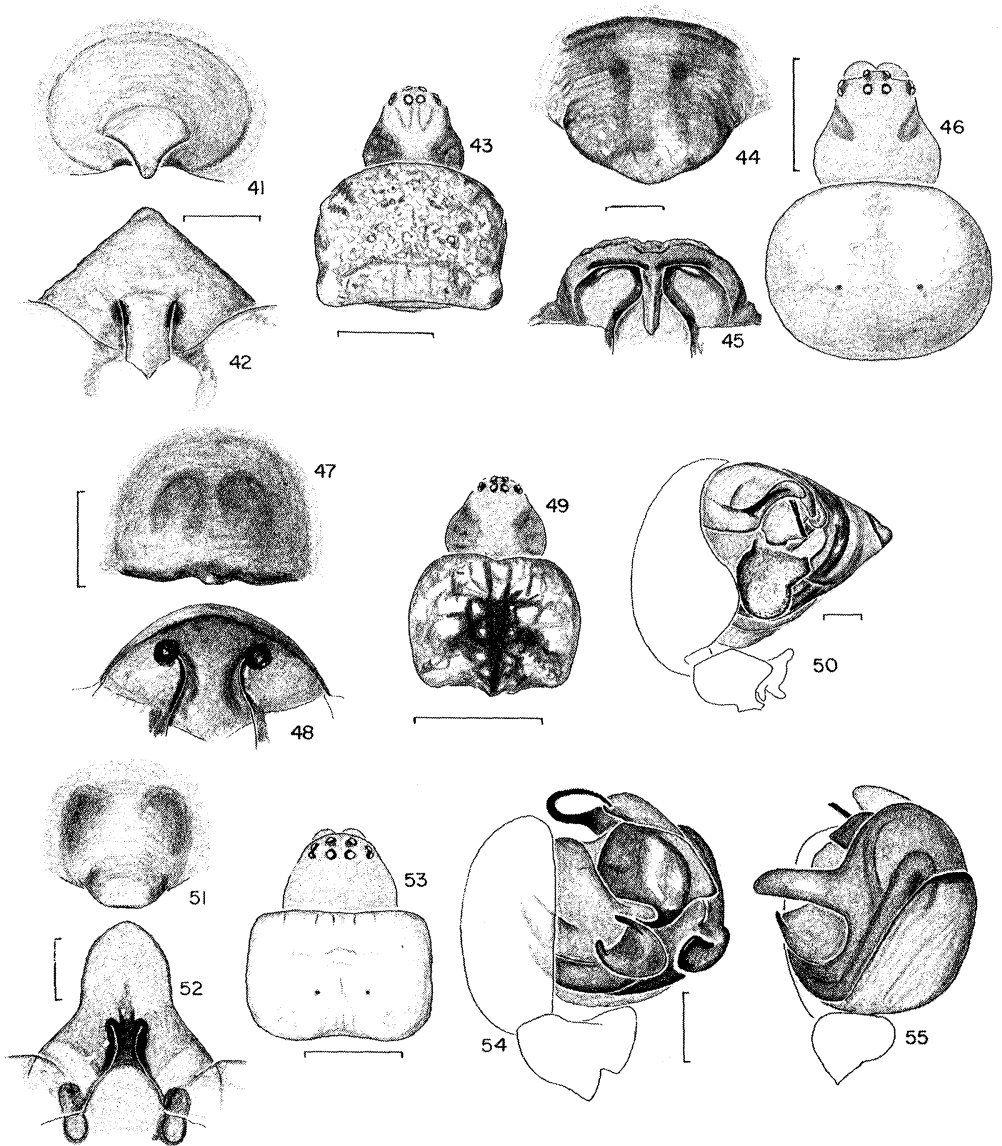

Figures 41-43. Bertrana nancho n. sp., female. 41, epigynum, ventral. 42, epigynum, posterior. 43 , dorsal.

Figures 44-46. B. arena n. sp., female. 44, epigynum, ventral. 45, epigynum, posterior. 46 , dorsal.

Figures 47-50. B. planada n. sp. 47-49, female. 47, epigynum, ventral. 48, epigynum, posterior, 49 , dorsal. 50, male, left palpus.

Figures 51-55. B. vella n. sp. 51-53, female. 51, epigynum, ventral. 52, epigynum, posterior. 53, dorsal. 54, 55, male. 54, palpus, mesal. 55, palpus, ventral. Scale lines. $1.0 \mathrm{~mm}$; genitalia $0.1 \mathrm{~mm}$. 
Paratypes. ECUADOR Tungurahua: Baños, $2100 \mathrm{~m}, 2$ May 1939, 39 (W. Clarke-Macintyre, AMNH); Tungurahua, $2600 \mathrm{~m}$, 6 May 1939, ô (W. Clarke-Macintyre, AMNH).

Bertrana vella new species

Figures 51-55; Map 2

Holotype. Female holotype and one female paratype from El Valle, Coclé, Panama, July 1936, A. M. Chickering in MCZ. The specific name is an arbitrary combination of letters.

Description. Female holotype: Carapace yellowish white. Chelicerae, labium, endites yellowish. Sternum black with a yellow band all around. Coxae, legs yellowish. Dorsum of abdomen white (Fig. 53); venter with white pigment blotches in center; sides white. Eyes subequal. Anterior median eyes 1.4 diameters apart, 0.9 from laterals. Posterior median eyes 1.4 diameters apart, 1.4 from laterals. Legs hairy, without macrosetae. Abdomen rectangular (Fig. 53). Total length $2.2 \mathrm{~mm}$. Carapace $1.2 \mathrm{~mm}$ long, 1.1 wide. First femur $0.98 \mathrm{~mm}$, patella and tibia 1.09 , metatarsus 0.73 , tarsus 0.44 . Second patella and tibia $0.91 \mathrm{~mm}$, third 0.71 , fourth 1.00 .

Male from Anchicaya: Color as in female except sternum light orange, and a pair of dusky marks on anterior edge of abdomen. Eyes subequal. Anterior median eyes 0.9 diameter apart, 0.4 from laterals. Posterior median eyes 0.7 diameter apart, 1.2 from laterals. Endite without tooth. Palpal patella with one macroseta. First coxa without hook. Second tibia thicker than first, without macrosetae. Abdomen oval, longer than wide. Total length $1.6 \mathrm{~mm}$. Carapace $0.88 \mathrm{~mm}$ long, 0.78 wide. First femur $1.17 \mathrm{~mm}$, patella and tibia 1.37 , metatarsus 1.04, tarsus 0.52 . Second patella and tibia $0.93 \mathrm{~mm}$, third 0.59 , fourth 0.91 .

Note. It is not certain that male and female are correctly matched.

Diagnosis. The long, ventrally drawn out epigynum (Fig. 51, 52) separates $B$. vella from other species; a projecting prong from the tegulum of the palpus separates the male (Fig. 55).

Paratypes. COLOMBIA Valle: Cent. Anchicaya, $400 \mathrm{~m}$, $ᄋ$ (W. Eberhard 840, MCZ), 30ิ, 1975 (W. Eberhard, MCZ). 
Amazonepeira new genus

Type species $A$. herrera. The generic name is feminine.

Diagnosis. Amazonepeira has genitalia resembling those of Araneus and Aculepeira. The genitalia differ from those of Alpaida and Bertrana in that the epigynum of the female bears a narrow annulate scape from an elaborate base and the male palpus has the conductor (C in Fig. 60) sitting on the rim of the tegulum (T), not on the inside, and without a basal paramedian apophysis.

Amazonepeira differs from Araneus and Aculepeira in having an oval abdomen, longer than wide, and by having the eyes large and closely spaced within a black patch, the medians closer to the laterals than to each other, a presumed apomorphy. Also there is only one palpal patellar seta, and the shape of the median apophysis is a quarter-circle with a graceful lateral spine. The terminal apophysis is unusually small for species related to Araneus.

Only one species is known.
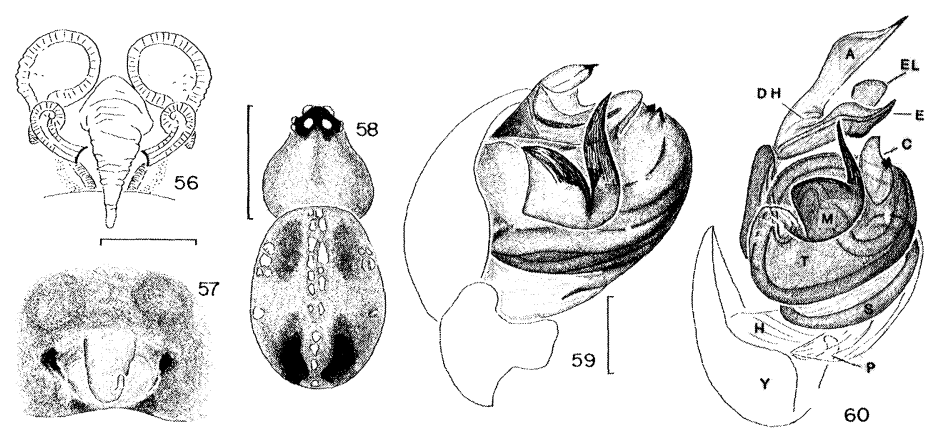

Figures 56-60. Amazonepeira herrera n. sp. 56-58, female. 56, epigynum, cleared. 57, epigynum, ventral. 58, dorsal. 59, 60, male, left palpus. 59, mesal. 60 , pulled apart. Abbreviations. A, terminal apophysis; C, conductor; DH, distal hematodocha; E, embolus; $\mathrm{H}$, hematodocha; $\mathrm{M}$, median apophysis; $\mathrm{P}$, paracymbium; $\mathrm{S}$, subtegulum; T, tegulum; Y, cymbium. Scale lines. $1.0 \mathrm{~mm}$; genitalia $0.1 \mathrm{~mm}$. 


\section{Amazonepeira herrera new species}

Figures 56-60; Map 2

Holotype. Female holotype, 6 female and one male paratypes from Genaro Herrera, $04^{\circ} 55^{\prime} \mathrm{S}, 73^{\circ} 45^{\prime} \mathrm{W}$, Loreto, Peru, 28 July 1988 (D. Silva D.) in MHNSM. The specific name is a noun in apposition after the type locality.

Description. Female from type locality: Carapace orange, crimson on sides, eye region black. Chelicerae, labium, endites orangered. Sternum orange-red. Coxae yellow; legs yellowish with narrow black rings. Dorsum of abdomen yellowish with a median band of white spots, white spots on sides, and two pairs of crimson patches, each of the posterior pair containing a black patch (Fig. 58). Venter yellowish with anterior orange-red patch; spinnerets black. Posterior median eyes 1.2 diameters of anterior medians, laterals 0.6 diameter. Anterior median eyes 0.6 diameter apart, 0.6 from laterals. Posterior median eyes 0.6 diameter apart, 0.5 from laterals. Abdomen oval (Fig. 58). Total length $2.8 \mathrm{~mm}$. Carapace $1.3 \mathrm{~mm}$ long, 1.0 wide. First femur $1.7 \mathrm{~mm}$, patella and tibia 1.7, metatarsus 1.3 , tarsus 0.7 . Second patella and tibia $1.3 \mathrm{~mm}$, third 0.8 , fourth 1.4 .

Male from type locality: Color as in female. Posterior median eyes 0.8 diameter of anterior medians, laterals 0.6 diameter. Anterior median eyes 1 diameter apart, 0.8 from laterals. Posterior median eyes 1 diameter apart, 0.9 from laterals. Endite with tooth; palpal femur without tooth. Palpal patella with one macroseta. First coxa with large projecting hook. Second tibia thicker than first, with 3 macrosetae on distal end; a groove on second femur. Abdomen oval. Total length $2.8 \mathrm{~mm}$. Carapace $1.3 \mathrm{~mm}$ long, 1.0 wide. First femur $1.7 \mathrm{~mm}$, patella and tibia 1.8, metatarsus 1.3 , tarsus 0.7 . Second patella and tibia $1.2 \mathrm{~mm}$, third 0.7 , fourth 1.3 .

Variation. There is considerable variation in color, especially in the extent of the red and black patches.

Paratypes. PERU Amazonas: alto Río Comaina (Puesto Vigilancia 22), 850-1150 m, 21 Oct.-3 Nov. 1987, 2ㅇ, ô (D. Silva, MHNSM). Madre de Dios: $15 \mathrm{~km}$ E Puerto Maldonado on Río Madre de Dios, 200 m, 27 May 1983, \& (G. C. Hunter, ?CAS). 


\section{Literature Cited}

ArCher, A. F. 1958. Studies in the orbweaving spiders (Argiopidae) 4. Amer. Mus. Nov. 1922: 1-21.

Bonnet, P. 1955. Bibliographia Araneorum. Toulouse, 2(1): 1-918. 1956. Bibliographia Araneorum. Toulouse, 2(2): 919-1925.

BRignoli, P. 1983. A catalogue of the Araneae described between 1940 and 1981. Manchester Univ. Press, Manchester. 755 pp.

CAPORIACCO, L. DI. 1947. Diagnosi preliminari di specie nuove di aracnidi della Guiana Britanica. Monit. Zool. Italiano 56: 20-34.

Chickering, A. 1963. The female of Bertrana hieroglyphica Petrunkevitch (Araneae, Argiopidae). Psyche 70: 129-132.

Keyserling, E. 1880 . Neue Spinnen aus Amerika, I. Verhandl. zoolog. botan. Gesell. Wien, 29: 293-350.

1884. Neue Spinnen aus Amerika, V. Verhandl. zoolog. botan. Gesell.Wien, 33: 649-684.

1885. Neue Spinnen aus Amerika, VI. Verhandl. zoolog. botan. Gesell. Wien, 34: 489-534. 1-377.

Levi, H. W. 1986. The neotropical orb-weaver genera Chrysometa and Homalometa (Araneae: Tetragnathidae). Bull. Mus. Comp. Zool. 151: 91-215.

1988. The neotropical orb-weaving spiders of the genus Alpaida (Araneae: Araneidae). Bull. Mus. Comp. Zool. 151: 365-487.

in press. The neotropical and Mexican species of the orb-weaver genera Araneus, Dubiepeira and Aculepeira (Araneae: Araneidae). Bull. Mus. Comp. Zool.

Mello-Leitão, C. 1945. Arañas de Misiones, Corrientes y Entre Rios. Revista del Museo de la Plata (N. S. Zool.), 4: 213-302.

Petrunkevitch, A. 1925. Arachnida from Panama. Transact. Connecticut Acad. Arts Sci. 27: 51-248.

Roewer, C. Fr. 1942. Katalog der Araneae, Bremen. 1: 1-1040.

Simon, E. 1893. Descriptions d'espèces et de genres nouveaux de l'ordre des Araneae. Annal. Soc. entomol. France 62: 299-330.

Soares, B. A. M. and H. F. de Almeida Camargo. 1948. Aranhas coligidas pela Fundação Brasil-Central (Arachnida-Araneae). Bolet. Museu Paraense E. Goeldi, 10: 355-409. 

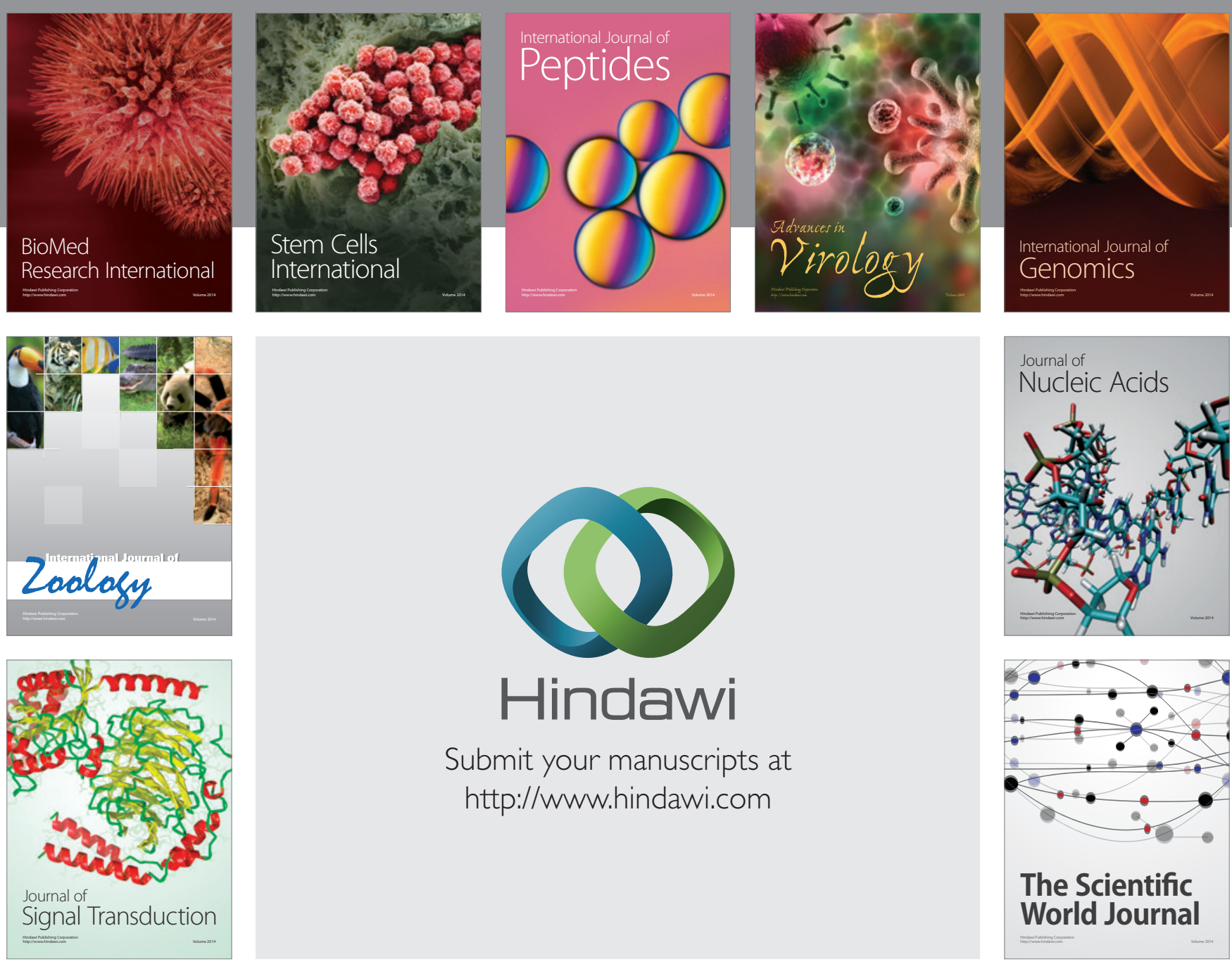

Submit your manuscripts at

http://www.hindawi.com
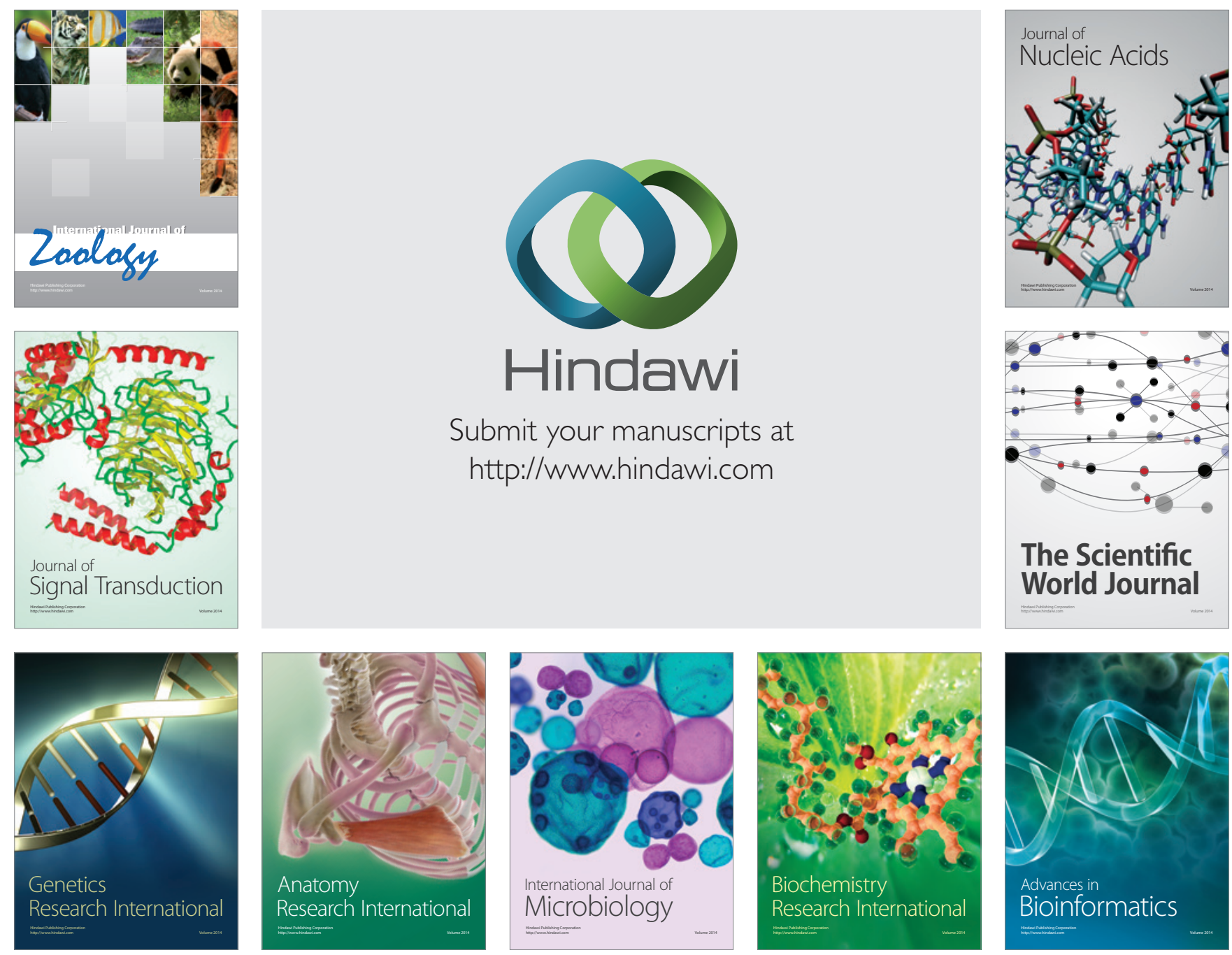

The Scientific World Journal
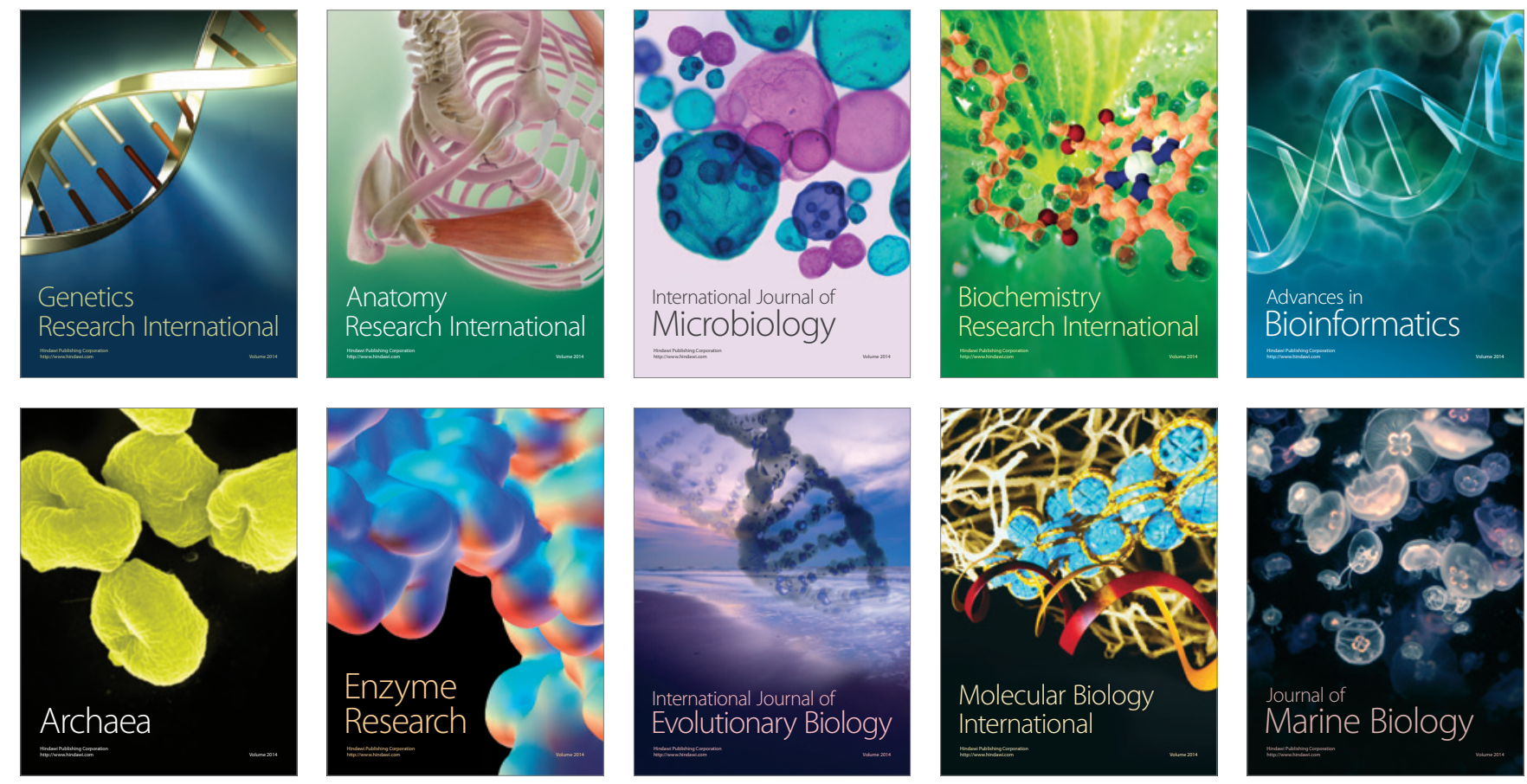